\title{
Genetic Divergence for Yield, Physiological and Quality Traits in Super-Early Pigeon pea (Cajanus cajan. (L.) Millsp.)
}

\author{
H.B. Shruthi ${ }^{1,2}$, A.J. Hingane ${ }^{1 *}$, M. Reddi Sekhar ${ }^{2}$, C.V. Sameer Kumar ${ }^{3}$, \\ L. Prashanthi ${ }^{2}$, B .V. Bhaskar Reddy ${ }^{2}$, P. Sudhakar ${ }^{2}$, J. Srivarsha ${ }^{1}$, \\ T.M. Bhosle ${ }^{1}$, Anil Kumar. $V^{1}$ and A. Rathore ${ }^{1}$ \\ ${ }^{1}$ Pigeonpea Breeding, International Crops Research Institute for Semi-arid Tropics \\ Patancheru, Telangana, 502324, India \\ ${ }^{2}$ Department of Genetics and Plant Breeding, S.V.Agricultural College, ANGRAU, Tirupati, \\ Andhra Pradesh, 517501, India \\ ${ }^{3}$ Pulses Breeding Division, Regional Agricultural Research Station, Palem, PJTSAU, \\ Hyderabad, Telangana, \\ *Corresponding author
}

\begin{abstract}
A B S T R A C T
The present investigation aimed to study genetic divergence and clustering pattern of 37super-early pigeon pea genotypes. Analysis of variance and

Keywords

Super-early, pigeonpea, genetic divergence, Cajanus cajan

Article Info

Accepted:

22 December 2019 Available Online: 20 January 2020 hierarchical cluster analysis of tocher's method revealed significant differences among the genotypes for all the traits under study. Based on genetic distance $\left(\mathrm{D}^{2}\right.$ value), the 37 genotypes were grouped into 9 distinctive clusters, of which cluster I and II formed the largest clusters with 10 genotypes in each. Among all the characters understudy, leaf area index(LAI) at 60 DAS contributed more to the divergence followed by leaf area (17.02) and leaf area index (12.71) at maturity. Based on the average inter-cluster distance, the cluster III and IX (66.93) tailed by cluster III and VIII (64.86) and cluster VI and VIII (64.06) showed higher inter-cluster distance depicting the wider divergence. Trait-wise selection of diverse parents from the above clusters aids in exploitation of heterosis in superearly pigeon pea.
\end{abstract}

\section{Introduction}

Pigeonpea is pro-farmer crop grown in the tropical and sub-tropical regions of Asia,
Africa, and the Caribbean. Globally cultivated in 7 Mha with production and productivity of 6.8 MT and $969 \mathrm{kgha}^{-1}$ respectively (FAOSTAT, 2019).Consumed as dal in India, 
also known for fodder, fuelwood, soil amelioration, fencing and thatching purposes (Mula and Saxena, 2010). Under a changing climate scenario, water is a limiting factor in current day agriculture. Since a great scale of maturity is now available in pigeonpea, the development of genotypes with the earlymaturity is the first line of defence in counter to terminal drought stress (Chauhan et al., 1992). Efforts are made at ICRISAT, Patancheru to develop a novel 'super-early' maturity group of pigeonpea.

Super-early pigeonpea maturing in 90-100 days opens the avenue to explore pigeonpea in off-season and non-traditional niches, aiming the upsurge in national production. Photo-insensitivity is reported to be linked to earliness (Wallis et al., 1981) is an add-on in super-early pigeonpea along with semi-dwarf stature. Being hardy and early fits in rice fallows, wheat-pulses and sugarcane-pulses intercropping system using residual moisture for growth and development (Hingane et al., 2018). Early genes, aids in rapid generation turnover, cutting the drudgery of longer breeding cycles.

Synchrony in maturity and attractive stature opens the prospect of mechanization in pigeonpea (Ranjani et al., 2018). With these wider opportunities in pigeonpea, an attempt to explore the genetic diversity in 37 genotypes of super-early pigeonpea for yield, yield attributes, physiological and quality traits was made to foresee the future breeding scope.

\section{Materials and Methods}

The experimental material comprised of 37 super-early pigeonpea genotypes laid out at pigeonpea breeding fields, ICRISAT, Patancheru during Kharif 2016. The study material consisted of 13 determinate types (DT) and 21 non-determinate types (NDT) with two DT checks MN1, MN5, and one NDT check ICPL 20325. Each genotype was sown in 4 rows of $4 \mathrm{~m}$ length with a spacing of $30 \times 10 \mathrm{~cm}$ in Randomized Complete Block Design (RCBD) with 2 replications. The experimental plot was located at $17.51^{\circ} \mathrm{N}$ latitude, $78.27^{\circ} \mathrm{E}$ longitude, an altitude of 545 meters above MSL, with an annual rainfall of $877.8 \mathrm{~mm}$ and alfisol being soil type. Field observations for traits viz., plant height $(\mathrm{cm})$, number of primary branches plant ${ }^{-1}$, pods plant $^{-1}$, seeds pod $^{-1}$, grain weight plant ${ }^{-}$ ${ }^{1}(\mathrm{~g}), 100$ seed weight $(\mathrm{g})$ and harvest index (\%) were recorded, on five randomly selected plants whereas days to $50 \%$ flowering, days to maturity and yield hectare ${ }^{-1}(\mathrm{~kg})$ was calculated on plot basis.

Dry matter content(g) at 30DAS, 60DAS and maturity, leaf area $\left(\mathrm{cm}^{2}\right)$ at 30DAS, 60DAS, and maturity were recorded on five randomly uprooted plants at (30 days interval) whereas canopy volume $\left(\mathrm{cm}^{3}\right)$ : Rodríguez, et al., 2008, leaf area index (LAI):Watson (1952) at 30DAS, 60DAS and maturity, crop growth rate $(\mathrm{CGR})\left(\mathrm{gm}^{-2} \mathrm{~d}^{-1}\right)$ :Radford (1967), net assimilation rate (NAR) $\left(\mathrm{gm}^{-2} \mathrm{~d}^{-1}\right)$ :Williams (1946), leaf area duration (LAD) ( ${ }^{2}$ days) between 30-60DAS and 60DAS-maturity ;Hunt (1978), protein content (\%):Sahrawat et al., (2002), phenol content (mg GAE 100' $\left.{ }^{1} \mathrm{~g}\right)$ :Singleton and Rossi (1965), dal cooking time (min): Sethi et al., (2014): Singh et al., (1984): Akinoso and Oladeji (2017)and dal recovery (\%): Sawargaonkar (2010)were calculated methodically. Standard cultural practices were followed to maintain good crop stand.

Data collected were subjected to analysis of variance using SAS v. 9.4 program (SAS, 2017).Genetic divergence was computed by multivariate analysis using Mahalanobis $\mathrm{D}^{2}$ statistics. The entries were congregated into clusters following Euclidean method as described by (Rao, 1952). 


\section{Results and Discussion}

The analysis of variance for all the thirty traits depicted significant differences (Table 1).The hierarchical cluster analysis of tocher's method classified 37 super-early pigeonpea genotypes into 9 distinctive clusters (Table 3). Among the nine clusters formed, cluster I and II turnedout to be the biggest cluster housing 10 genotypes each whereas cluster VIII and IX housed single genotype each (Table 2). A close relationship was witnessed in the genotypes grouped under the same cluster than diverse clusters. The intra and inter cluster $\mathrm{D}^{2}$ values among 9 clusters are presented in Table 3.

The dendrogram of 37 super-early pigeonpea genotypes depiciting the spatial position of each cluster in relation to others is presented in Fig.1. The intra-cluster distances ranged from 54.33 to 68.04 . The maximum intracluster distance was observed in cluster VI (68.04) followed by cluster III (63.09) and cluster I (59.48) portraying less genetic variability within the group making selection ineffective (Sreelakshmi and Shivani, 2015).

The higher inter-cluster distance was observed between cluster III and IX (66.93) followed by cluster III and VIII (64.86) and in cluster VI and VIII(64.06) suggesting wider genetic diversity (Table 2, Fig:1). The genotypes in these clusters can be utilized as potential parents and crossing between these genotypes would result in high heterotic expression for yield attributes, physiological and quality traits.

Thus deployment of genotypes from the above clusters in hybridization programme would reapnovel segregants (Dhubey et al., 2018). On the contrary, cluster IV and VIII (52.25) followed by cluster IV and VII (55.76) and cluster V and VII (56.44) showed the least inter-cluster distance, signifying a close relationship between the genotypes. Selection of such genotypes results in unproductive breeding. Similar reports were observed by Thombre et al., (2000), Sreelakshmi and Shivani (2015) and Ramya et al., (2018). Cluster means for yield, yield attributes, physiological and quality traits are given in Table $4 a, b$ and $c$ respectively.

A significant amount of variation among the cluster means for traits under study was also portrayed in the present study. Cluster IX revealed highest cluster mean for days to $50 \%$ flowering, days to maturity, plant height, canopy volume, yield hectare ${ }^{-1}$, dry mater content, leaf area and leaf area index at 30DAS, 60 DAS and at maturity, crop growth rate and leaf area duration between (30DAS60 DAS) and (60 DAS- Maturity). Cluster I testified highest cluster mean for number of primary branches plant $^{-1}$, seeds $\operatorname{pod}^{-1}$,seed yield plant ${ }^{-1}$ and harvest index respectively.

Cluster II topped for 100 seed weight whereas cluster VII crowned for net assimilation rate between (30DAS-60 DAS) and (60 DASmaturity) and dal recovery. Cluster V and VI reported highest mean for protien and phenol content respectively (Table 4c).Trait wise coherent selection of genotypes from above clusters, yields desirable improvement in novel super-early pigeonpea. These findings are in agreement with Sreelakshmi and Shivani (2015), Patel et al., (2018), Rajamani et al., (2014) and Kumara et al., (2013).

Among 30 traits under study, the highest contribution towards genetic diversity was by leaf area index at 60 DAS (26.71\%) followed by leaf area (17.02) and leaf area index (12.71) at maturity. Least contribution was from protein content and dal recovery $(0 \%)$.Figure 2, illustrates the contribution of each trait towards diversity. 
Table.1 Analysis of Variance for yield, yield attributes and quality traits in 37 super-early pigeonpea genotypes

\begin{tabular}{|c|c|c|c|c|}
\hline \multirow[t]{2}{*}{ Sl.No } & \multirow[t]{2}{*}{ Traits } & \multicolumn{3}{|c|}{ Mean sum of squares } \\
\hline & & $\begin{array}{c}\text { Replication } \\
\text { (1) }\end{array}$ & $\begin{array}{c}\text { Genotypes } \\
\text { (36) }\end{array}$ & $\begin{array}{c}\text { Error } \\
(36)\end{array}$ \\
\hline 1 & Days to $50 \%$ flowering & 2.61 & $10.44 * *$ & 0.83 \\
\hline 2 & Days to maturity & 1.68 & $13.69 * *$ & 3.05 \\
\hline 3 & Plant height $(\mathrm{cm})$ & 0.01 & $857.62 * *$ & 4.63 \\
\hline 4 & Number of primary branches plant ${ }^{-1}$ & 2.30 & $0.83 * *$ & 0.45 \\
\hline 5 & Pods plant ${ }^{-1}$ & 0.41 & $86.67 * *$ & 8.00 \\
\hline 6 & Seeds pod ${ }^{-1}$ & 0.16 & $0.02 * *$ & 0.00 \\
\hline 7 & 100 seed weight $(\mathrm{g})$ & 0.47 & $0.28 * *$ & 0.01 \\
\hline 8 & Canopy volume $(\mathrm{cm} 3)$ & 0.04 & $211510 * *$ & 954.27 \\
\hline 9 & Seed yield plant ${ }^{-1}(\mathrm{~g})$ & 2.29 & $4.45^{* *}$ & 0.53 \\
\hline 10 & Yield ha ${ }^{-1}(\mathrm{Kg})$ & 2.37 & $140687 * *$ & 46302.00 \\
\hline 11 & Harvest Index (\%) & 0.04 & $50.76^{* *}$ & 4.30 \\
\hline 12 & Dry matter content $(\mathrm{g})$ at $30 \mathrm{DAS}$ & 0.81 & $13.9 * *$ & 0.39 \\
\hline 13 & Dry matter content $(\mathrm{g})$ at $60 \mathrm{DAS}$ & 1.19 & $50.31 * *$ & 1.40 \\
\hline 14 & Dry matter content $(\mathrm{g})$ at maturity & 2.27 & $200.06 * *$ & 4.08 \\
\hline 15 & Leaf area $\left(\mathrm{cm}^{2}\right)$ at 30 DAS & 1.77 & $4458.05^{* *}$ & 6.90 \\
\hline 16 & Leaf area $\left(\mathrm{cm}^{2}\right)$ at 60 DAS & 1.40 & $43076^{* *}$ & 18.64 \\
\hline 17 & Leaf area $\left(\mathrm{cm}^{2}\right)$ at maturity & 0.55 & $42761 * *$ & 21.07 \\
\hline 18 & Leaf area index at $30 \mathrm{DAS}$ & 0.78 & $0.04 * *$ & 0.00 \\
\hline 19 & Leaf area index at 60 DAS & 1.36 & $0.46 * *$ & 0.00 \\
\hline 20 & Leaf area index at maturity & 0.47 & $0.46 * *$ & 0.00 \\
\hline 21 & $\begin{array}{l}\text { Crop growth rate }\left(\mathrm{gm}^{-2} \mathrm{~d}^{-1}\right) \text { between } 30 \\
\text { DAS \& } 60 \text { DAS }\end{array}$ & 0.51 & $15.85 * *$ & 1.09 \\
\hline 22 & $\begin{array}{l}\text { Crop growth rate }\left(\mathrm{gm}^{-2} \mathrm{~d}^{-1}\right) \text { between } 60 \\
\text { DAS \& maturity }\end{array}$ & 3.50 & $26.799 * *$ & 1.96 \\
\hline 23 & $\begin{array}{l}\text { Net assimilation rate }\left(\mathrm{gm}^{-2} \mathrm{~d}^{-1}\right) \text { between } \\
30 \text { DAS \& } 60 \text { DAS }\end{array}$ & 0.74 & $0.0001581 * *$ & 0.00 \\
\hline 24 & $\begin{array}{l}\text { Net assimilation rate }\left(\mathrm{gm}^{-2} \mathrm{~d}^{-1}\right) \text { between } \\
60 \text { DAS \& maturity }\end{array}$ & 1.21 & $0.000268 * *$ & 0.00 \\
\hline 25 & $\begin{array}{l}\text { Leaf area duration between } 30 \text { DAS \& } \\
60 \text { DAS }\end{array}$ & 1.80 & $184.14 * *$ & 0.10 \\
\hline 26 & $\begin{array}{l}\text { Leaf area duration between } 60 \text { DAS \& } \\
\text { maturity }\end{array}$ & 2.86 & $1135.11 * *$ & 8.21 \\
\hline 27 & Protein content $(\%)$ & 16.98 & $0.15^{*}$ & 1.13 \\
\hline 28 & Phenol content (mg GAE100g ${ }^{-1}$ ) & 2.08 & $2580.88 * *$ & 783.63 \\
\hline 29 & Dal cooking time (min) & 70.09 & $527.69 * *$ & 0.29 \\
\hline 30 & Dal recovery $(\%)$ & 2.91 & $40.22 * *$ & 1.50 \\
\hline
\end{tabular}

Note:* and $* *$ Significant at $0.05,0.01$ levels of probability. 
Table.2 Classification of 37 super-early genotypes into nine different clusters based on $\mathrm{D}^{2}$ analysis

\begin{tabular}{|c|l|c|}
\hline Clusters & \multicolumn{1}{|c|}{ Genotypes } & No of genotypes \\
\hline I & $\begin{array}{l}\text { ICPL 11242, ICPL 11255, ICPL 11256, ICPL 11300, ICPL 11318, ICPL 11326, } \\
\text { ICPL 20328, ICPL 20337, ICPL 20340, MN1 }\end{array}$ & 10 \\
\hline II & $\begin{array}{l}\text { ICPL 11244, ICPL 11249, ICPL 11253, ICPL 11285, ICPL 11301, ICPL 11303, } \\
\text { ICPL 20325, ICPL 20329, ICPL 20336, ICPL 20338 }\end{array}$ & 10 \\
\hline III & ICPL 11245, ICPL 11298, ICPL 20326, ICPL 20335 \\
\hline IV & ICPL 11252, ICPL 11263, ICPL 11276, ICPL 20341 & 4 \\
\hline $\mathbf{V}$ & ICPL 11273, ICPL 20333 & 2 \\
\hline VI & ICPL 11259, ICPL 11279, ICPL 11296 & 3 \\
\hline VII & ICPL 11292, MN5 & 2 \\
\hline VIII & ICPL 11324 & 1 \\
\hline IX & ICPL 20327 \\
\hline Total & & 37 \\
\hline
\end{tabular}

Table.3 Average intra and inter cluster distances ( $\mathrm{D}^{2}$ values) for nine clusters of super-early pigeonpea genotypes

\begin{tabular}{|c|c|c|c|c|c|c|c|c|c|}
\hline Cluster & I & II & III & IV & V & VI & VII & VIII & IX \\
\hline I & $\mathbf{5 9 . 4 8}$ & 59.82 & 61.76 & 59.6 & 57.83 & 61.39 & 59.43 & 57.57 & 61.61 \\
\hline II & $\cdot$ & $\mathbf{5 9 . 1 3}$ & 60.19 & 58.98 & 59.03 & 61.37 & 60.35 & 57.24 & 59.15 \\
\hline III & $\cdot$ & $\cdot$ & $\mathbf{6 3 . 0 9}$ & 60.17 & 62.25 & 62.40 & 61.65 & 64.86 & 66.93 \\
\hline IV & $\cdot$ & $\cdot$ & $\cdot$ & $\mathbf{5 8 . 7 5}$ & 59.78 & 60.85 & 55.76 & 52.25 & 60.52 \\
\hline V & $\cdot$ & $\cdot$ & $\cdot$ & $\cdot$ & $\mathbf{5 8 . 9 3}$ & 61.41 & 56.44 & 60.56 & 58.29 \\
\hline VI & $\cdot$ & $\cdot$ & $\cdot$ & $\cdot$ & $\cdot$ & $\mathbf{6 8 . 0 4}$ & 58.75 & 64.06 & 63.55 \\
\hline VII & $\cdot$ & $\cdot$ & $\cdot$ & $\cdot$ & $\cdot$ & $\cdot$ & $\mathbf{5 4 . 3 3}$ & 62.49 & 57.94 \\
\hline VIII & $\cdot$ & $\cdot$ & $\cdot$ & $\cdot$ & $\cdot$ & $\cdot$ & $\cdot$ & $\mathbf{0 . 0 0}$ & 56.72 \\
\hline IX & $\cdot$ & $\cdot$ & $\cdot$ & $\cdot$ & $\cdot$ & $\cdot$ & $\cdot$ &. & $\mathbf{0 . 0 0}$ \\
\hline
\end{tabular}


Table.4 $a$ Cluster means of 37 super-early pigeonpea genotypes for eight quantitative traits

\begin{tabular}{|c|c|c|c|c|c|c|c|c|c|c|c|}
\hline Clusters & DF & DM & PH & NPB & PPP & SPP & SW & CV & YP & YH & HI \\
\hline I & 50.00 & 82.00 & 90.00 & $\mathbf{1 0 . 2 0}$ & 45.00 & $\mathbf{3 . 8 2}$ & 7.60 & 1431.00 & $\mathbf{1 4 . 8 0}$ & 1733.98 & $\mathbf{2 8 . 7 0}$ \\
\hline II & 51.00 & 82.00 & 91.00 & 9.10 & 44.00 & 3.79 & $\mathbf{8 . 0 0}$ & 1492.10 & 13.90 & 1528.10 & 26.30 \\
\hline III & 52.00 & 83.00 & 112.00 & 9.40 & $\mathbf{5 5 . 0 0}$ & $\mathbf{3 . 8 2}$ & 7.30 & 1706.70 & 14.40 & 1648.21 & 26.00 \\
\hline IV & 47.00 & 79.00 & 58.00 & 8.80 & 31.00 & 3.63 & 7.50 & 910.90 & 12.20 & 1732.57 & 25.80 \\
\hline V & 49.00 & 82.00 & 78.00 & 8.40 & 44.00 & 3.75 & 7.90 & 1251.20 & 14.00 & 1640.61 & 27.30 \\
\hline VI & 52.00 & 84.00 & 87.00 & 8.70 & 37.00 & 3.78 & 7.40 & 1360.90 & 14.10 & 1473.85 & 28.40 \\
\hline VII & 52.00 & 83.00 & 114.00 & 9.10 & $\mathbf{5 5 . 0 0}$ & 3.70 & 7.80 & 1867.40 & 14.50 & 1758.64 & 23.20 \\
\hline VIII & 51.00 & 84.00 & 114.00 & 8.20 & 54.00 & 3.47 & 7.40 & 1745.80 & 13.30 & 1564.95 & 20.30 \\
\hline IX & $\mathbf{5 4 . 0 0}$ & $\mathbf{8 4 . 0 0}$ & $\mathbf{1 2 9 . 0 0}$ & 7.80 & 44.00 & 3.66 & 7.30 & $\mathbf{1 9 7 4 . 6 0}$ & 13.30 & $\mathbf{1 9 4 3 3 . 2 8}$ & 17.80 \\
\hline
\end{tabular}

Table.4b Cluster means of 37 super-early pigeonpea genotypes for yield attributes

\begin{tabular}{|c|c|c|c|c|c|c|c|c|c|c|c|}
\hline \multirow[t]{2}{*}{ Clusters } & DM & DM & DM & LA & LA & LA & LAI & LAI & LAI & CGR & CGR \\
\hline & $@ 30$ & @ 60 & @ M & $@ 30$ & @ 60 & $@ \mathbf{M}$ & $@ 30$ & @ 60 & @ M & 30-60DAS & 60DAS-M \\
\hline I & 12.62 & 26.64 & 56.56 & 220.63 & 664.17 & 545.14 & 0.73 & 2.19 & 1.80 & 15.41 & 23.49 \\
\hline II & 11.71 & 24.37 & 53.39 & 204.07 & 615.01 & 495.94 & 0.67 & 2.03 & 1.64 & 13.96 & 22.29 \\
\hline III & 13.79 & 28.59 & 61.15 & 195.19 & 588.39 & 468.75 & 0.64 & 1.94 & 1.55 & 16.24 & 24.98 \\
\hline IV & 8.07 & 20.33 & 46.88 & 176.33 & 528.45 & 410.95 & 0.58 & 1.74 & 1.36 & 13.50 & 23.25 \\
\hline V & 9.66 & 23.31 & 51.32 & 271.48 & 815.31 & 697.80 & 0.89 & 2.69 & 2.30 & 14.99 & 23.19 \\
\hline VI & 12.64 & 25.19 & 54.55 & 172.10 & 518.76 & 399.93 & 0.57 & 1.71 & 1.32 & 13.85 & 22.23 \\
\hline VII & 14.42 & 29.87 & 63.74 & 194.17 & 604.38 & 464.42 & 0.64 & 1.99 & 1.53 & 16.93 & 25.69 \\
\hline VIII & 15.01 & 31.03 & 66.05 & 227.64 & 687.89 & 564.89 & 0.75 & 2.27 & 1.87 & 17.55 & 26.51 \\
\hline IX & 17.42 & 35.91 & 75.85 & 327.76 & 1090.10 & 970.59 & 1.08 & 3.60 & 3.20 & 20.19 & 29.46 \\
\hline
\end{tabular}


Table.4c Cluster means of 37 super-early pigeonpea genotypes for yield attributes and quality traits

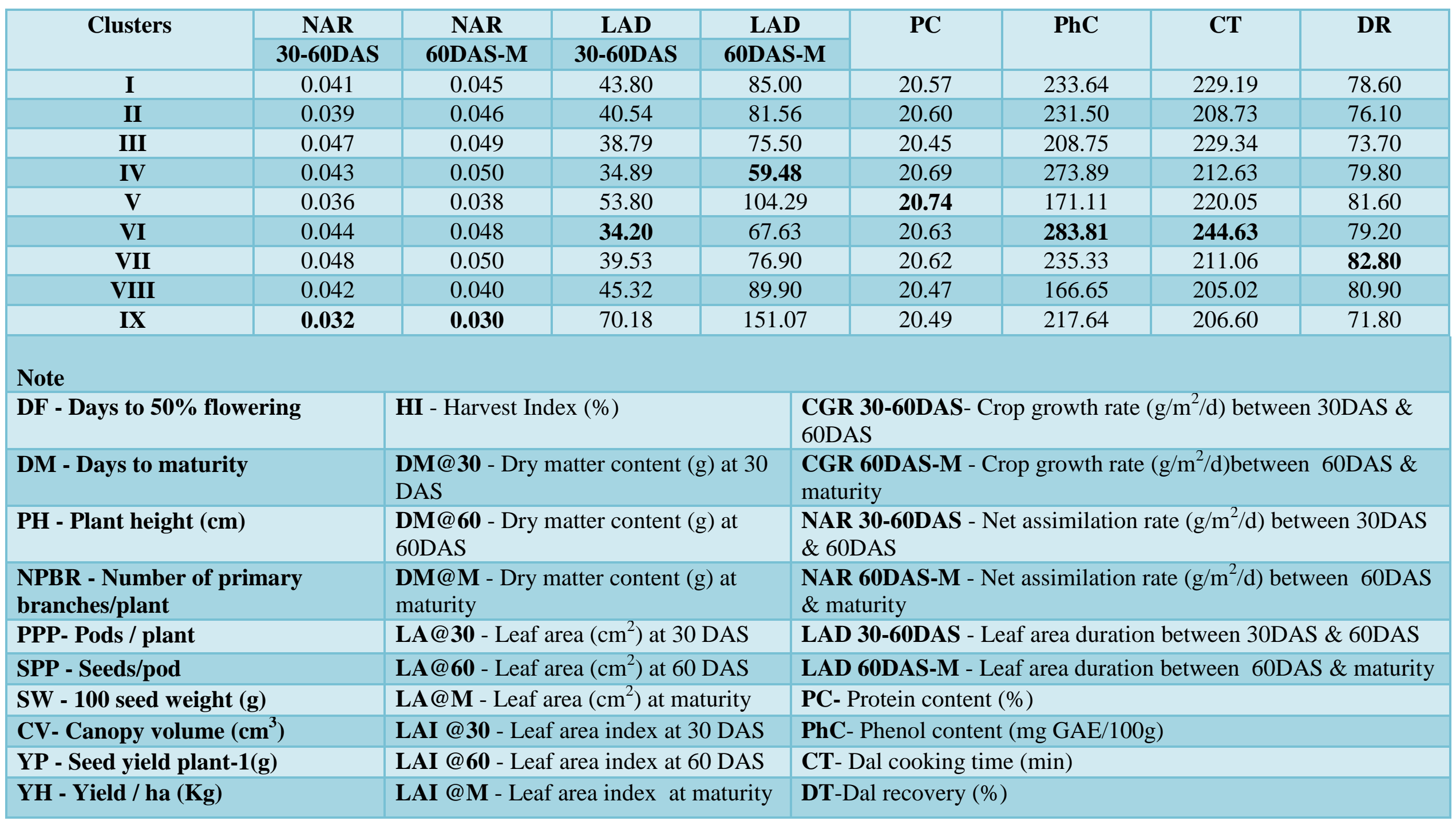




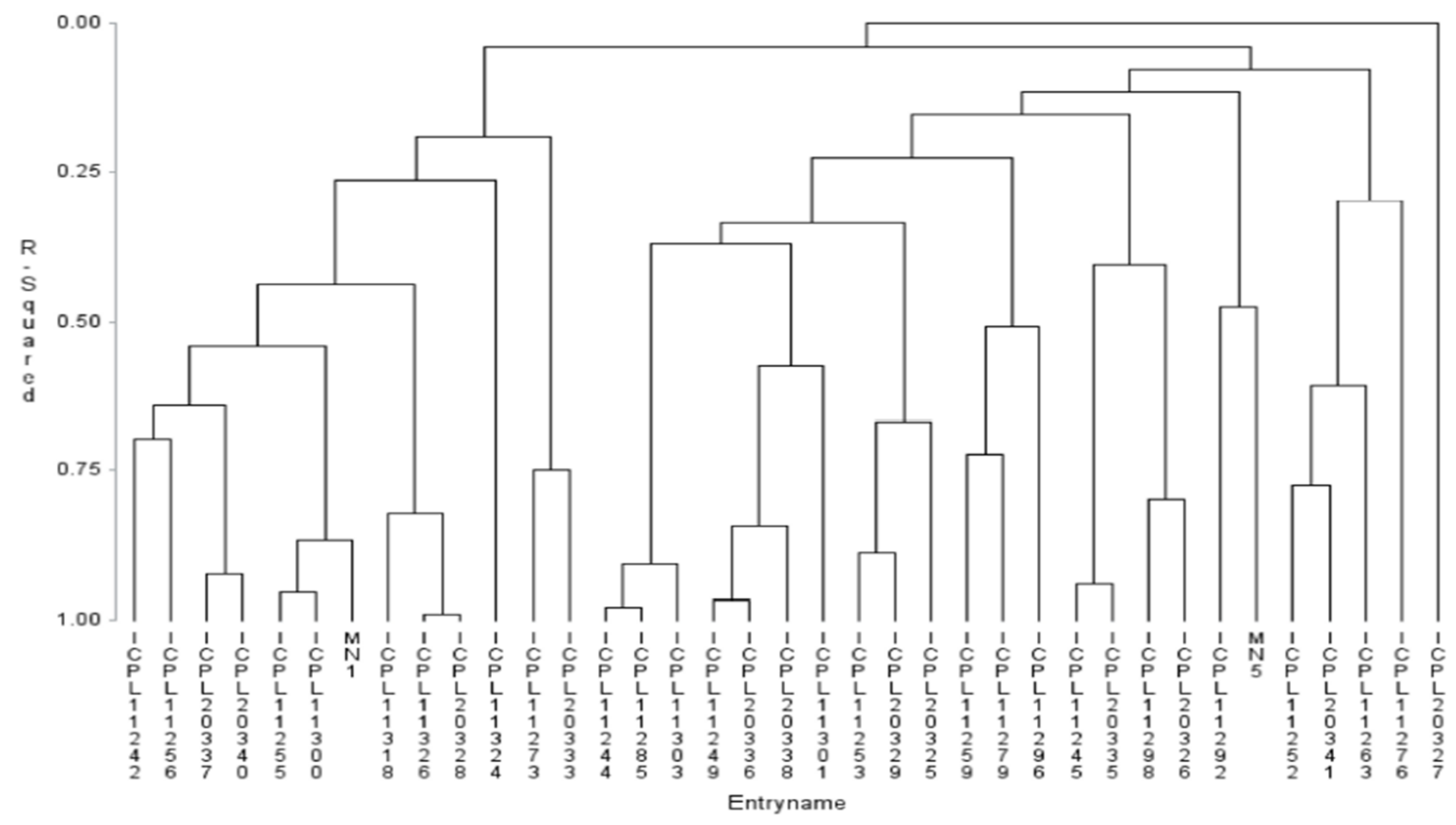

Figure.1 Dendrogram on clustering of super-early genotypes 


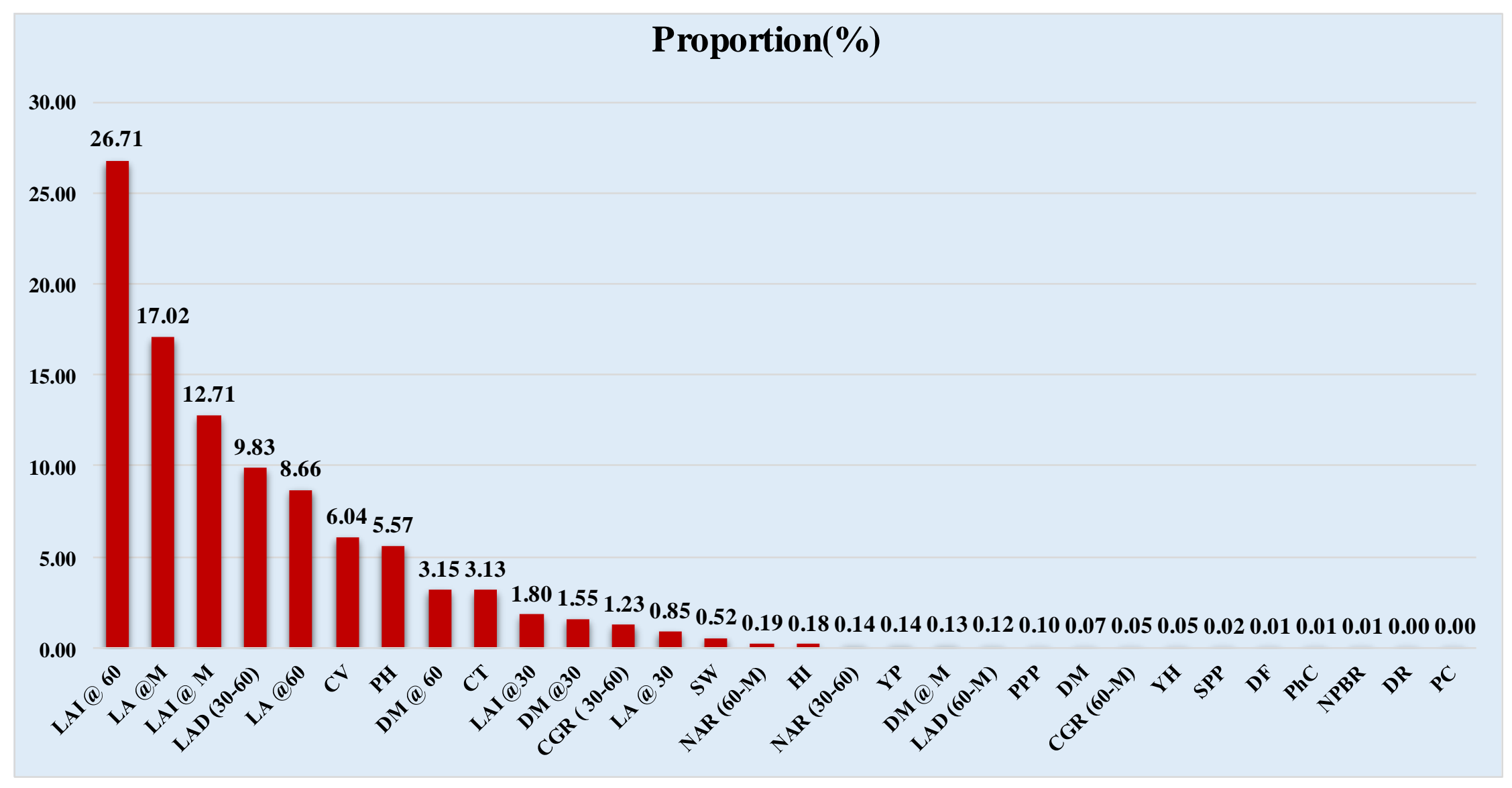

Figure.2 Percent contribution of different characters towards genetic divergence in super-early pigeonpea genotypes 
The traits with maximum contribution towards divergence should also be considered for selection of genotype in hybridization program for genetic improvement of pigeonpea. Sreelakshmi \& Shivani (2015) reported days to $50 \%$ flowering, pods plant ${ }^{1}$ and plant height contributing more to diversity whereas Patel et al., (2018) summarized plant height, days to $50 \%$ flowering, days to maturity and number of pods plant ${ }^{-1}$ as traits owing to genetic diversity.

Genetic diversity studies in super-early genotypes of pigeonpea aid the planning of crosses to exploit higher heterosis. The 37 super-early pigeonpea genotypes in the present study were classified into nine distinctive clusters.Cluster III and IX (66.93) followed bycluster III and VIII (64.86) and cluster VI and VIII (64.06) depicted higher inter-cluster distance affirming wider divergence.

Choice of genotypes from these clusters as potential parents in crop improvement would result in heterotic offsprings. Leaf area index at 60 DAS $(26.71 \%)$ followed by leaf area (17.02) and leaf area index (12.71) at maturity contributed maximum to the diversity accentuating the role of physiological trait in addition to yield traits in pigeonpea improvement.

\section{Ackowledgements}

It is to acknowledge and heart-fully thank Department of Science and Technology, Government of India, for funding my Ph.D. research by the INSPIRE fellowship programme. The services rendered by Jyothi and Rajesh, field technicians, Pigeonpea Breeding, ICRISAT in field operations are greatly acknowledged.

\section{References}

Akinoso, R. and Oladeji, O. D. 2017.
Determination of energy and time requirement for cooking pigeonpea (Cajanus cajan). Journal of Biosystems Engineering.42(1): 56-61.

Dubey, N., Avinashe, A. H. and Srivastava, A.N. 2018.Evaluation of genetic diversity among soybean [Glycine max (1.)] genotypes using multivariate analysis. Plant Archives. 18(1):908-912

FAOSTAT. $2019 . \quad$ Retrieved fromhttp://www.fao.org/faostat/en/\#data /QC.

Hingane, A.J., Kute, N. S., Singh, I., Kumar, N., Singh, S. J., Raje, R. S., Singh, I. P., Belliappa, S. H., Sadayappan, R. M, Rathore, A. R and Kumar, C. V. S. 2018.Prospects of Super-early Pigeonpea in the Pigeonpea Workshop at International Food Legumes Research Conference VII (IFLRC-VII) held at Marrakesh during 5-9 May, 2018.

Hunt, R 1978. Demography vs Plant growth analysis, New Phytologist, Edward Arnold, London. 8(1), 269-272.

Kumara, B. N., Santoshagowda, G. B., Nishanth, G. K. and Dharmaraj, P. S. 2013. Genetic diversity, variability and correlation studies in advanced genotypes of Pigeonpea [Cajanus cajan ( L .) Millsp .]. Acta Biologica Indica. 2(2): 406-411.

Mula, M. G. and Saxena, K. B. 2010.Lifting the level of awareness on pigeonpea- A global perspective. International Crops Research Institute for semi-arid tropics, 540. ISBN: 978-92-9066-55-9.

Nadarajan, N., Manivannan, $\mathrm{N}$ and Gunasekaran, M. 2016. Quantitative genetics and biometrical techniques in plant Breeding. 75-80. ISBN: 978-9272-5827-1.

Pandey, V. R., Tiwari, D. K., Yadav, S. K. and Pandey, P. 2015. Studies on direct selection parameters for seed yield and its components traits in pigeonpea (Cajanus cajan (L.) Millsp.). African 
Journal of Agricultural Research. 10(6), 485-490.

Patel, H. N., Patel, A. M. and Patel, J. M. 2018. Genetic divergence study through $\mathrm{D}^{2}$ analysis in pigeonpea (Cajanus cajan L . Millspaugh ).International journal of chemical studies.6(5):19471950.

Radford, P. J. (1967). Growth analysis formulae. Their use and abuse. Crop Sciences. 7: 171-175.

Rajamani, S., Sreekanth, M., Rao, Y. K. 2014. Genetic diversity studies for yield and yield attributing traits in pigeonpea [Cajanus cajan (L.) Millsp.]. Journal of Research ANGRAU.42: 21-26.

Ramya, K. R., Magudeeswari, P., Vanniyarajan, C., Gowthami, R., Indhu, S. M. and Monisha, K. 2018. Genetic divergence among pigeonpea genotypes using mahalonobis $\mathrm{D}^{2}$ statistics. International Journal of Current Microbiology and Applied Sciences.7(06): 510-514.

Ranjani, M. S., Vanniarajan, C. Kumar, C. V. S., Saxena, R. K., Sudhagar, R. and Hingane, A. J. 2018. Genetic variability and association studies for yield and its attributes in super-early pigeonpea ( Cajanus cajan (1.) Millsp.) genotypes. Electronic Journal of Plant Breeding.9(2): 682-691.

Rao, C. R. 1952. Advanced statistical methods in biometrical research. John Wiley and Sons, Inc. New York.

Rodríguez, S. B., Urrutia, V. M. M., Roblesgonzález, M. M. and Timothy, W. 2008. Performance of various grapefruit (Citrus paradisiMacf .) and pummelo (C . maximaMerr.) cultivars under the dry tropic conditions of Mexico. Euphytica.164: 27-36.

Sahrawat, K. L., Ravi Kumar, G. and Murthy, K. V. 2002. Sulfuric acid-Selenium digestion for multi-element analysis in a single plant digests. Communications in
Soil Science and Plant Analysis.33: 3757-3765.

Sawargaonkar, S. L. 2010. Study of heterosis, combining ability, stability and quality parameters in CGMSbased pigeonpea [Cajanus cajan (L.) Millsp.] hybrids. Thesis, Marathwada Agricultural University, Parbhani. 56-57.

Sethi, S., Samuel, D. V. K., Khan, I. 2014. Development and quality evaluation of quick-cooking dhal - A convenience product. Journal of Food Science and Technology.51:595-600.

Shinde, Y. H., V, A., Joshi, J. B. and Pandit, A. B. 2017. Kinetics of cooking of unsoaked and presoaked split peas ( Cajanus cajan ). Journal of Food Process Engineering. 1-7.

Singh, U., Jain, R. C., Jambunathan, R. J. and Faris, P. G. 1984. Nutritive value of vegetable pigeonpea, mineral trace elements, Journal of Food Science. 49: 645.

Singleton, V.L. and Rossi, J.A. (1965). Colorimetry of total phenolics with phosphomolybdic- phospho-tungstic acid reagents. American Journal of Enology and Viticulture. 16: 144-158.

Sreelakshmi, C and Shivani, D. 2015. Germplasm evalution in pigeonpea , Cajanus cajan MILLSP . Using Mahalanobis $\mathrm{D}^{2}$ statistics. Journal of Global Biosciences. 4(7): 2828-2832.

Thombre, B. B., Aher, R.P. and Dahat, D.V. 2000. Genetic divergence in Pigeonpea [Cajanus cajan (L.) Millsp.].Indian journal of Agricultural Research. 34: 126-129.

Wallis E. S., Byth D. E. and Saxena K. B. 1981. Flowering responses of thirtyseven early maturing lines of pigeonpea. In: Nene Y. L, Kumble V. (ed) Proceedings of the international workshop on pigeonpea, International Crops Research Institute for the Semiarid Tropics (ICRISAT), Patancheru.2: 
143-159.

Watson, D. J. 1952. The physiological basis of variation in yield. Advances in Agronomy.4: 101-145.
Williams, R. F. 1946. The physiology of plant growth with special reference to the concept of net assimilation rate. Annals of Botany. 10: 41-72.

\section{How to cite this article:}

Shruthi, H.B., A.J. Hingane, M. Reddi Sekhar, C.V. Sameer Kumar, L. Prashanthi, B .V. Bhaskar Reddy, P. Sudhakar, J. Srivarsha, T.M. Bhosle, Anil Kumar. V and Rathore. A. 2020. Genetic Divergence for Yield, Physiological and Quality Traits in Super-Early Pigeonpea (Cajanus cajan. (L.) Millsp.). Int.J.Curr.Microbiol.App.Sci. 9(01): 2422-2433. doi: https://doi.org/10.20546/ijcmas.2020.901.276 